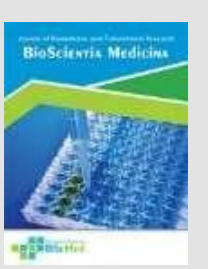

Bioscientia Medicina: Journal of Biomedicine \& Translational Research

Journal Homepage: www.bioscmed.com

\title{
The Role of Extracorporeal Membrane Oxygenation on Acute Respiratory Distress Syndrome
}

\section{Dini Ardiyani ${ }^{*}$, Zen Ahmad ${ }^{2}$}

${ }^{1}$ Fellowship student of Pulmonology Division, Department of Internal Medicine, Faculty of Medicine, Universitas Sriwijaya, Palembang, Indonesia

${ }^{2}$ Division Pulmonology, Department of Internal Medicine, Faculty of Medicine, Universitas Sriwijaya, Palembang, Indonesia.

\section{A R T I C L E I N F O}

\section{Keywords:}

Acute respiratory distress syndrome Acute lung injury

Extracorporeal membrane oxygenation

Lung protective ventilation

\section{*Corresponding author:}

Dini Ardiyani

\section{E-mail address:}

dinipdl@gmail.com

All authors have reviewed and approved the final version of the manuscript.

https://doi.org/10.32539/bsm.v5i10.362

\begin{abstract}
A B S T R A C T
Acute lung injury and acute respiratory distress syndrome are characterized by rapid-onset respiratory failure following a variety of direct and indirect insults to the parenchyma or vasculature of the lungs. Extracorporeal membrane oxygenation is a form of extracorporeal life support where an external artificial circulator carries venous blood from the patient to a gas exchange device (oxygenator) where blood becomes enriched with oxygen and has carbon dioxide removed. This blood then reenters the patients circulation. The potential advantages of ECMO over conventional manajement may extend beyond its role in supporting patients with ARDS. ECMO may facilitate and enhance the application of lung-protective ventilation by minimizing ventilator-induced lung injury.
\end{abstract}

\section{Introduction}

Acute respiratory distress syndrome (ARDS) is noncardiogenic pulmonary edema caused by alveolar injury, secondary to an inflammatory process, pulmonary or systemic. ${ }^{1}$ The pathogenesis of ARDS is not completely clear, and there is no gold standard for establishing the diagnosis. The American European Consensus Conference (AECC) introduced ARDS and acute lung injury (ALI) definitions. ALI is characterized by a milder degree $(\mathrm{PaO} 2 / \mathrm{FiO} 2<300)$ with the same cause and pathophysiology as ARDS. 1,4

ARDS is a common form of lung injury characterized by disruption of the alveolar-capillary membrane resulting in pulmonary edema and hypoxemia.5,6 Initiation of ECMO for adult ARDS should be considered if conventional therapy cannot maintain adequate oxygenation. 6,7

\section{Definition of ARDS}

Ashbaug and colleagues first put forward the definition of ARDS in 1967.2,8 The American-European Consensus Conference (AECC) described ARDS in 1994 as acute hypoxemia, the ratio of arterial oxygen partial pressure to the inspired oxygen fraction $\mathrm{PaO} 2 / \mathrm{FiO} 2$ $200 \mathrm{mmHg}$, bilateral infiltrates on chest X-ray, without evidence of cardiogenic pulmonary edema, pulmonary arterial wedge pressure (PAWP) $18 \mathrm{mmHg}$ or no signs of increased left atrial pressure. ${ }^{6}$ In 2011, the European Society of Intensive Care Medicine was supported by the American Thoracic Society of Critical Care Medicine 
developed the Berlin definition for ARDS. Table 1 shows

the definition of ARDS based on the Berlin criteria.

Table 1. ARDS definition based on Berlin criteria, 2011.9,10

\begin{tabular}{ll}
\hline ARDS & Criterias \\
\hline Time & $\begin{array}{l}\text { Respiratory symptoms that have just been felt or that are getting worse, } \\
\text { occur within } 1 \text { week }\end{array}$
\end{tabular}

Thorax image Bilateral opacity, not caused by effusion, atelectasis or pulmonary nodules

Oedema source Caused by respiratory failure, not caused by heart failure or fluid overload

Hypoxemia severity

Low $\quad-200 \mathrm{mmHg}_{2}<\mathrm{PaO}_{2} / \mathrm{FiO}_{2} \leq 300 \mathrm{mmHg}$ with PEEP or CPAP $\geq 5 \mathrm{cmH}_{2} \mathrm{O}$

Moderate - $100 \mathrm{mmHg}_{2} \mathrm{PaO}_{2} / \mathrm{FiO}_{2}<200 \mathrm{mmHg}^{2}$ dengan PEEP $>5 \mathrm{cmH}_{2} \mathrm{O}$

Severe $\quad-\quad \mathrm{PaO}_{2} / \mathrm{FiO}_{2} \leq 100 \mathrm{mmHg}$ dengan $\mathrm{PEEP} \geq 5 \mathrm{cmH}_{2} \mathrm{O}$

\section{ARDS pathogenesis}

The etiology of ARDS is primarily due to pneumonia caused by viruses, bacteria, or fungi, and the next most common cause is severe sepsis due to other infections outside the lungs. ${ }^{11,12}$ On the alveolar surface, 90\% consists of type 1 pneumocyte cells which function for gas exchange which takes place by passive diffusion. Type 1 alveolar epithelial cells of the alveolar wall, capillary endothelial cells, basement membrane, and the space between the two membranes is called the perimicrovascular interstitium. Innate immune defense mechanisms, including the formation of extracellular neutrophil traps and the release of histones, may help capture pathogens but may exacerbate an alveolar injury. ${ }^{13,15}$

In healthy lungs, endothelial stabilization is mediated by vascular endothelial cadherin (VEcadherin), an endothelial-specific protein required to maintain the integrity of the endothelial barrier in lung microvessels. During lung injury, increased concentrations of thrombin, tumor necrosis factoralpha (TNF- $\alpha$ ), vascular endothelial growth factor (VEGF), and leukocyte signaling in the lungs agitate VE-cadherin binding. They were resulting in increased endothelial permeability and accumulation of alveolar fluid. ${ }^{16}$ Inflammatory damage to the pulmonary endothelium results in increased capillary permeability, thereby leading to pulmonary edema. In addition to endothelial permeability, epithelial permeability also has a vital role in the pathogenesis of ARDS. The alveolar epithelial barrier is similar to that of the endothelium. Under pathological conditions, neutrophil migration causes epithelial injury by disrupting cell-to-cell junctions, causing apoptosis and denudation, which ultimately increases the permeability of the alveolar epithelium. Figure 1 describes the mechanism of increased capillaryalveolar permeability in ARDS. 17

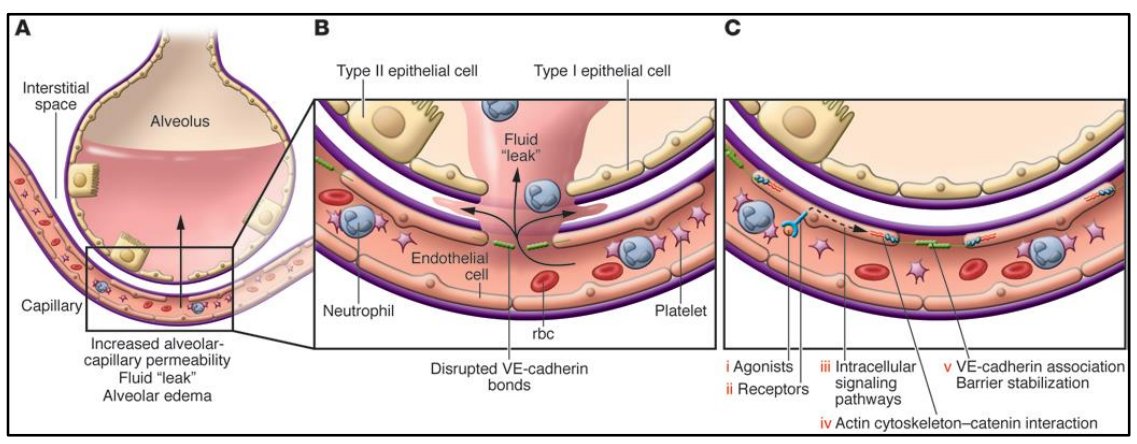

Figure 1. Mechanism of increased capillary-alveolar permeability ARDS17 
The pathophysiology of ARDS involves the accumulation of fluid in the alveoli caused by vascular inflammation. In ARDS, the formation of edema is usually triggered by inflammation of the lung tissue, which is often caused by an exaggerated response to pathogens or trauma. This further allows infiltration of immune cells through the perivascular interstitium into infected alveolar cells. As a secondary event, termed vascular leakage or permeability, protein-rich fluid from the vascular capillaries enters the perimicrovascular interstitium and alveolar spaces in the alveoli. Flooding in the lungs interferes with the exchange of oxygen and carbon dioxide gases in the pulmonary capillaries. ${ }^{10,15}$

Filling of air spaces with edematous fluid causes hypoxemia, necessitating mechanical ventilation. Vascular injury and alveolar edema contribute to a decreased ability to excrete CO2 (hypercapnia), leading to increased lung dead space ARDS. In contrast, hypercapnia impairs sodium transport, reducing clearance of alveolar edema. After the onset of primary disease, inflammation of the injured alveoli occurs in three successive phases. There are three phases of alveolar damage in ARDS in anatomical pathology: exudative, proliferative, and fibrotic phases.

\section{ARDS management}

Management of ARDS can be classified as specific and supportive therapy. Specific steps include maintenance of gas exchange and manipulation of the underlying pathophysiology. Supportive therapy includes sedation, mobilization, nutrition, and prophylaxis of venous thromboembolism.

\section{Extracorporeal Membrane Oxygenation (ECMO)}

ECMO is a temporary mechanical support system used to assist heart and lung function in patients with respiratory failure and severe heart failure. ${ }^{21}$ Based on guidelines made by ELSO (extracorporeal life support organization), indications for ECMO include: hypoxic respiratory failure due to any cause (primary or secondary) extracorporeal life support should be considered if the risk of death is $50 \%$ or more and indicated if the risk of death is $80 \%$ or more. this $50 \%$ risk of death is associated with a $\mathrm{PaO} 2 / \mathrm{FiO} 2<150$ at FiO2 $>90 \%$ and a Murray score of $2-3$. The $80 \%$ risk of death is associated with a $\mathrm{PaO} 2 / \mathrm{FiO} 2<100$ at FiO2 > 90\% and a Murray score of 3 - 4, under optimal care for more than 6 hours. The success of ECMO in respiratory failure when ECMO is given early after onset (1 - 2 days); CO2 retention on mechanical ventilation despite high plate (plateau pressure) (> 30 cmH2O); severe air leak syndrome; needed for intubation in patients undergoing lung transplantation; sudden respiratory or cardiac collapse. 23

The Murray score is only a guide for determining the initiation of ECMO in ARDS patients. The calculation method is to give each component a value with a value of 0 to 4 . The final score is calculated by adding the parts (parameters) and dividing by the fundamental component. Score 0 no injury, score $1-2.5$ mild to moderate lung injury, and score > 2.5 severe lung injury.22,24,25 Table 2 describes the parameters of the Murray score, using four parameters to evaluate the severity of lung injury in ARDS patients.

Table 2. Murray score 24

\begin{tabular}{|c|c|c|c|c|c|c|}
\hline \multicolumn{7}{|c|}{ Murray score } \\
\hline Parameter/score & & 0 & 1 & 2 & 3 & 4 \\
\hline $\begin{array}{l}\mathrm{PaO}_{2} / \mathrm{FiO}_{2} \quad\left(\mathrm{FiO}_{2}\right. \\
\mathrm{mmHg}\end{array}$ & $100 \%)$ & $\begin{array}{l}<300 \\
(>40 \mathrm{kPa})\end{array}$ & $\begin{array}{l}225-299 \\
(30-40)\end{array}$ & $\begin{array}{l}175-224 \text { (23- } \\
30)\end{array}$ & $\begin{array}{l}100-174 \\
(13-23)\end{array}$ & $\begin{array}{l}<100 \\
(<13)\end{array}$ \\
\hline CXR & & Normal & I poin per & drant infiltrate & & \\
\hline PEEP & & $\leq 5$ & $6-8$ & $9-11$ & $12-24$ & $\geq 15$ \\
\hline Compliance $\mathrm{ml} / \mathrm{cml}$ & & $\geq 80$ & $60-79$ & $40-59$ & $20-39$ & $\leq 19$ \\
\hline
\end{tabular}

Notes: abbreviation: $\mathrm{CXR}=$ Chest $\mathrm{X}$-Ray, FiO2 = oxygen fraction inspiration, $\mathrm{PaO} 2=$ partial oxigen pressure, $\mathrm{PEEP}=$ Positive end expiratory pressure. 
Based on the 2009 CAESAR clinical trial, which evaluated the indications for ECMO in ARDS patients, including Murray score 3-4 or $\mathrm{pH}<7.20$ even though conventional treatment was optimal, Murray score $>2$ and $\mathrm{PaO} 2 / \mathrm{FiO} 2$ ratio $<150 \mathrm{mmHg}$ should be considered for moved to ECMO center. ${ }^{24,26}$

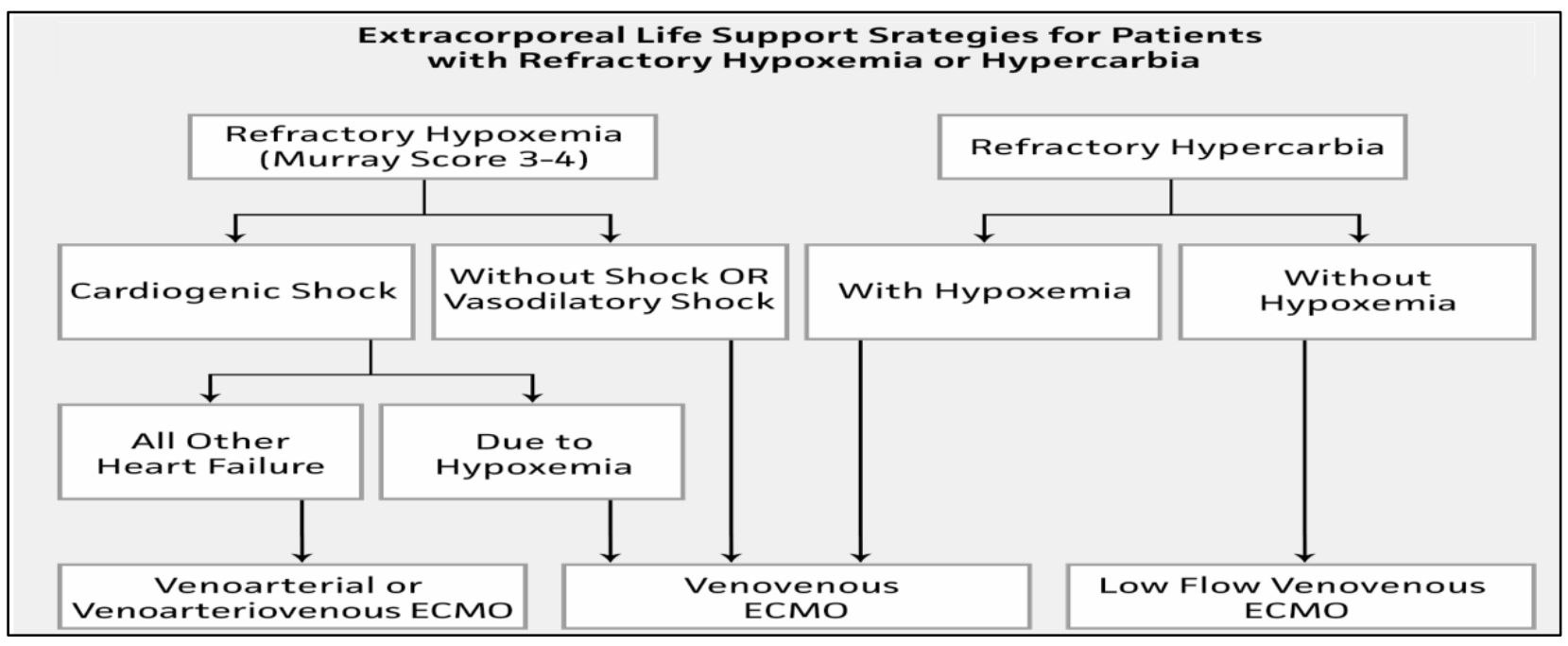

Figure 2. Extracorporeal Life Support Strategy in Hypoxaemic or Refractory Hypercarbia Patients. 27

\section{ECMO configuration type on ARDS}

The ECMO mode is determined by the location of the access and return cannula. The ECMO accesses deoxygenated venous blood from the systemic circulation, pressurizes it using a pump and passes it through a membrane oxygenator, and then returns it to the circulation on the other side of the vein. The circuit consists of two main types of configuration: venovenous and arteriovenous. Figure 3 describes the configuration of the central venovenous ECMO. ${ }^{28}$

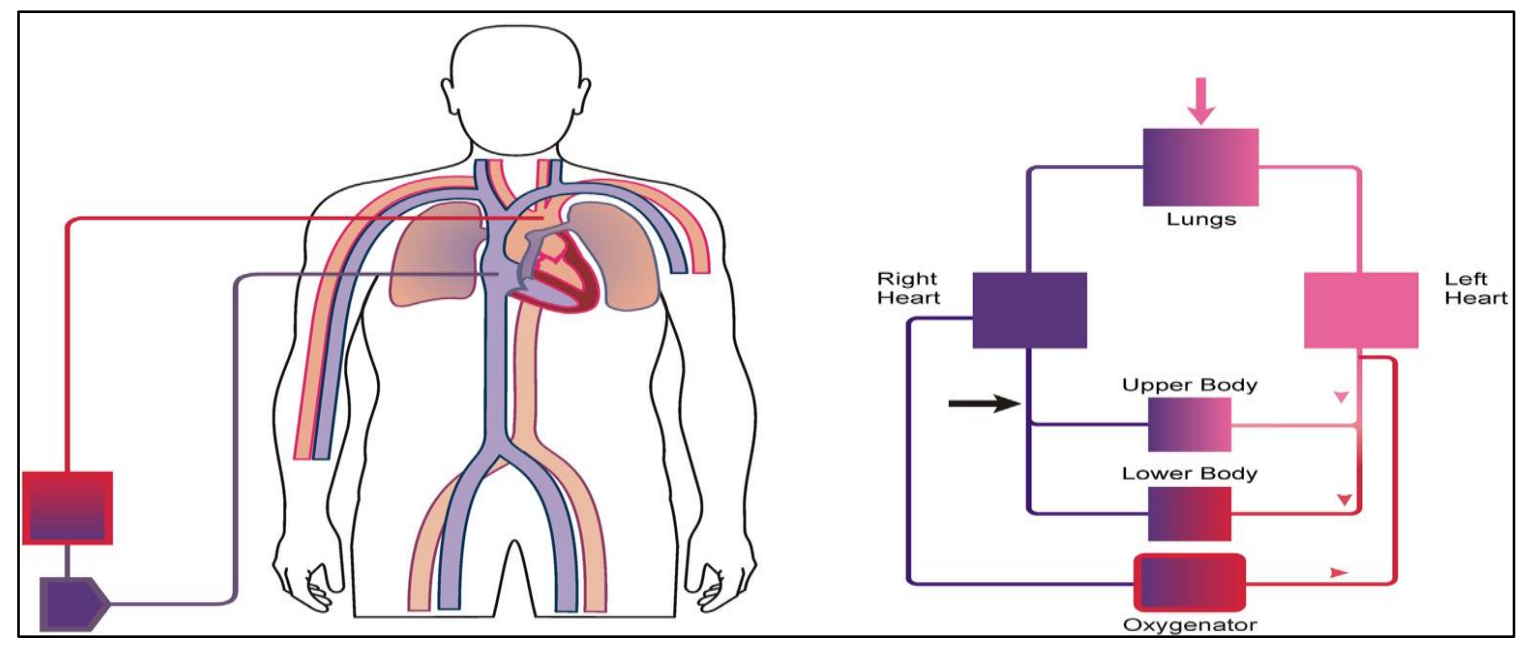

Figure 3. ECMO configuration on central venovenous ${ }^{28}$

Peripheral ECMO-VA cannulation is most often performed in conjunction with angiography. Utilization of the subclavian artery and internal jugular vein reduces the risk of upper body perfusion abnormalities.
This subclavian artery cannulation has not been widely adopted.28 Figure 4 shows the peripheral venoarterial ECMO configuration. 


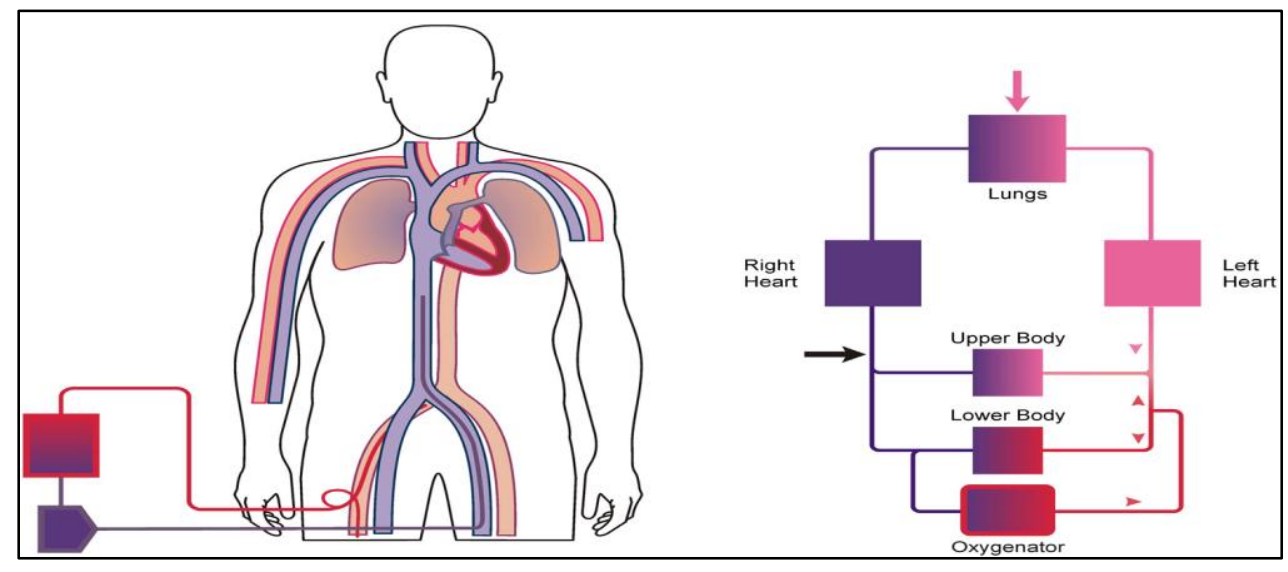

Figure 4. ECMO configuration- peripheral venoarterial ${ }^{28}$

Venovenous ECMO: is a configuration in which blood is deoxygenated, drawn from the central vein via a pump, passed through an oxygenator, and infused back into the central vein. Venovenous ECMO only provides respiratory support and is the configuration of choice in cases of severe ARDS.7 For ARDS without heart failure, two VV access models can be used: Two cannulas, access via the femoral vein (drainage) and the internal jugular vein for reinfusion (inflow). There is also access that is used a bifemoral approach; the access cannula is inserted percutaneously through the left femoral vein. Blood flows through the pump to the oxygenator and is returned to the right atrium via a cannula inserted percutaneously from the right femoral vein cannula.

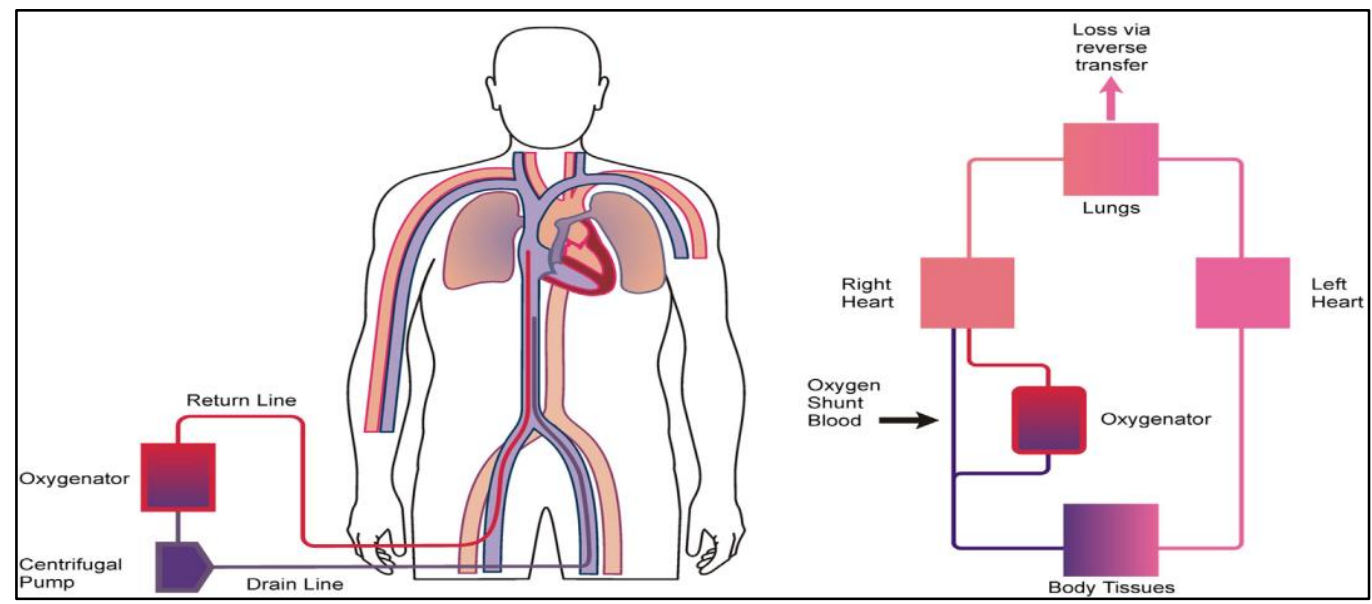

Figure 5. Two cannula ECMO-venovenous configuration 28

A single cannula (double-lumen) via internal jugular vein: Avalon and Origen double lumen cannula have a large lumen for drainage and a smaller lumen for reinfusion. The inflow lumen is a side orifice that can be oriented towards the tricuspid valve. The drainage lumen is positioned as far from the reinfusion lumen as possible to minimize recirculation. The Avalon cannula is designed to be placed in the inferior vena cava. Its placement requires imaging, usually fluoroscopy, so cannulation is more complicated than accessing two cannulas. The advantage of single cannula access is that it is easier to mobilize and move the patient. Disadvantages are that imaging is required during placement, and the cannula can be pulled out of the inferior vena cava into the right atrium. $23,28,29$

\section{ECMO initiation on ARDS}

The standard ECMO circuit consists of a blood pump, oxygenator, drainage, return cannula, flow and pressure sensor, heat exchanger for cooling or heating blood, arterial and venous access points for blood 
collection in the circuit. There are access routes located along the ECMO circuit (arterial-venous access point) for drug and fluid infusion and collection of laboratory tests, in addition to pressure sensors (pre-membrane and post-membrane) and flow sensors. ${ }^{28,30-32}$ ECMO installation is common. They are performed in the operating room by a cardiothoracic surgeon. Blood flow (50-70 ml/kg) and oxygen flow are adjusted according to oxygen saturation and blood gas analysis to maintain a $\mathrm{PaO} 2$ of $60-80 \mathrm{mmHg}$ and a partial pressure of carbon dioxide $35-45 \mathrm{mmHg}$. Before initiation, an ultrasound of the lungs, heart, abdomen, blood vessels, and chest $\mathrm{x}$-ray is necessary. A pulmonary protective ventilator strategy was adopted after ECMO initiation (FiO2 < 40\%, tidal volume $2-4 \mathrm{ml} / \mathrm{kg}$, plateau pressure $<25 \mathrm{cmH} 2 \mathrm{O}$, and respiratory rate $8-10$ breaths $/ \mathrm{min} .{ }^{33}$

The anticoagulant heparin unfractionated (UFH) was used for all patients, with a bolus dose of $50 \mathrm{U} / \mathrm{kg}$ 10 minutes before cannulation. If the activated clotting time $(\mathrm{ACT})$ is < 180 seconds, the continuous intravenous infusion of $\mathrm{UFH}$ is increased at a rate of 2$20 \mathrm{U} / \mathrm{kg} /$ hour, with a target ACT of 180-200 seconds and an activated partial thromboplastin time (aPTT) of 50-80 seconds (or 1.5 times the baseline). ${ }^{33}$ Figure 6 shows a flowchart of ECMO initiation on ARDS.

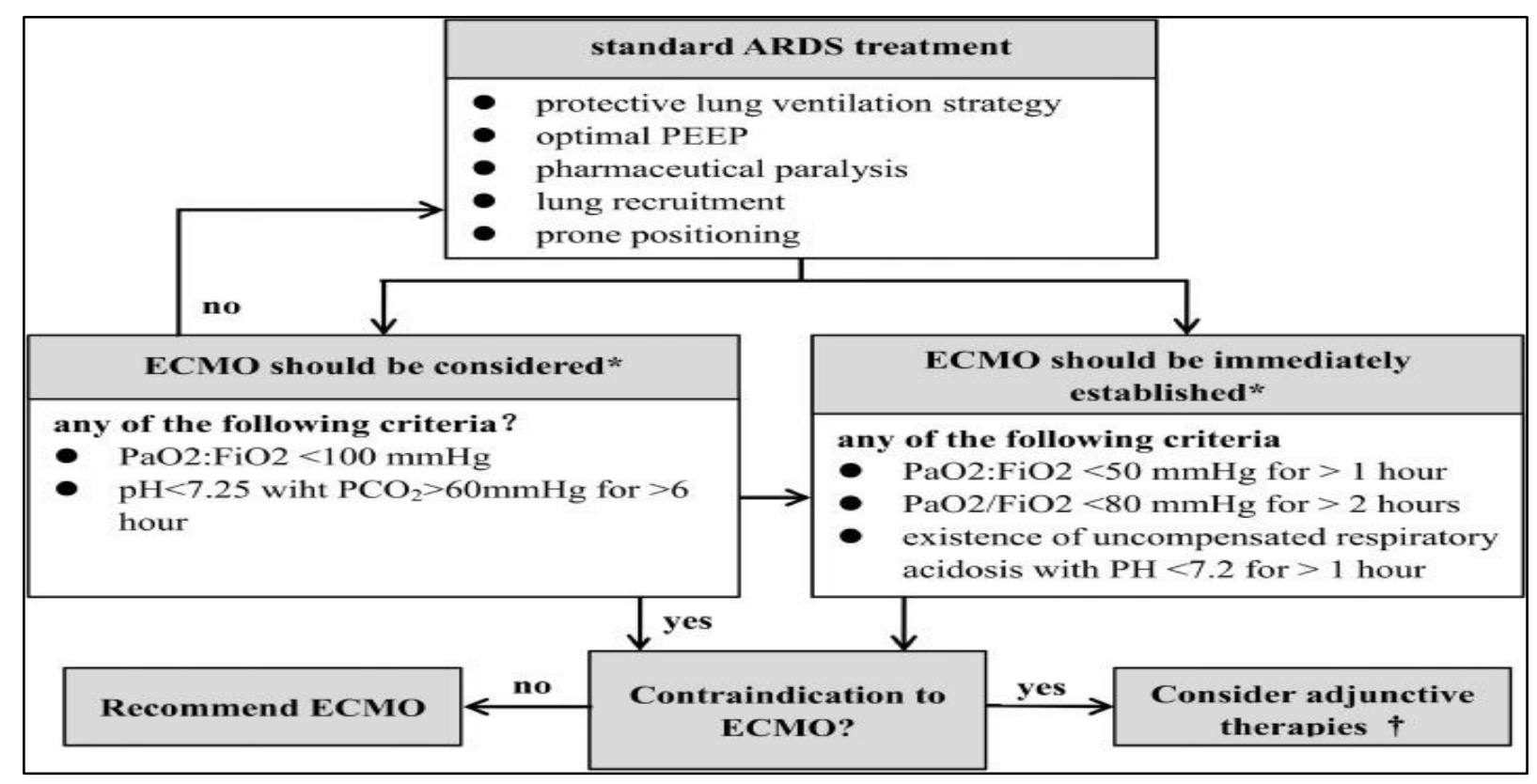

Figure 6. Initiation protocol flowchart ECMO in ARDS. ${ }^{33}$

\section{Standard ECMO weaning procedure}

ECMO weaning begins when there is an improvement after observing the results of chest Xray/CT, blood gas analysis, respiratory mechanism, and other indicators. The sweep-to-flow ratio was maintained at $1: 1$, and the ECMO flow was gradually reduced to $2.5 \mathrm{~L} / \mathrm{min}$ while the same mechanical ventilation parameters were continued.33 With the ECMO flow maintained at $2.5 \mathrm{~L} / \mathrm{min}$, and the ECMO sweep was gradually reduced until cessation total sweep. For ECMO weaning, the following criteria are maintained for 24-48 hours at an ECMO flow rate of $2.5 \mathrm{~L} / \mathrm{min}$ without sweeping, provided that hemodynamically stable, significant improvement in ventilation function and gas exchange, as evidenced by chest X-ray and lung ultrasound, $\mathrm{PaO} 2 / \mathrm{FiO} 2>150$ $\mathrm{mmHg}$, partial pressure of carbon dioxide $50 \mathrm{mmHg}$, respiratory rate 20 times per minute, body temperature $<380$ C, Murray index < 3, hematocrit > 35\%.

The possibility of discontinuing ECMO is a condition of no hope of survival, severe brain damage, severe irreversible multiorgan failure, or no restoration of cardiac and pulmonary function. The optimal time to determine the absence of recovery will vary at different ECMO centers. For ECMO-VV, there is no recovery of heart function in many ECMO centers for 3-5 days, 
while in patients using ECMO-VV, there is no recovery of lung function after 2-3 weeks. ${ }^{34}$

\section{Conclusion}

The potential advantages of ECMO over conventional manajement may extend beyond its role in supporting patients with ARDS. ECMO may facilitate and enhance the application of lung-protective ventilation by minimizing ventilator-induced lung injury.

\section{References}

1. Levy B, Choi A. Acute respiratory distress Syndrome. In: Loscalzo J (Ed). Harrison's Pulmonary and Critical Care Medicine. 2nd Ed. New York: McGraw-Hill Education, 2013: 28894.

2. Sweeney MR, McAuley DF. Acute respiratory distress syndrome. Lancet, 2016, 388: 241630 .

3. Ware LB. Patophysiology of ARDS. Oxford text book of critical care. 2nd ed. April 2016.

4. Aokage T, Palmer K, Ichiba S, Takeda S. Extracorporeal membrane oxgenase for acute respiratory distress syndrome. Journal of Intensive Care, 2015, 3:17.

5. Saguil A. Acute Respiratory Syndrome: Diagnosis and Management. Am Fam Physician, 2012, 85(4):352-8.

6. Fishman JA, Kotloff RM, Pack AI, Senior RM. Acute respiratory failure. In: Fishman's pulmonary diseases and disorder. 5th ed. New York: McGraw-Hill education, 2010.2162-327.

7. Parekh M, Abrams D, Brodie D, Yip M. Extracorporeal membrane oxygenation for ARDS: optimizing of lung protective ventilation.

8. Lee W, Slutsky A. Acute hypoxemic respiratory failure and ARDS. In: Broaddus VC, Ernst JD, Tek JR, Lzarus SC (Eds). Murray and Nadel's Textbook of Respiratory Medicine. 6th Ed. Philadelphia: Elsevier. 2016. 1740-60.

9. Ranieri VM, Rubenfeld GD, Thompson BT, et al. Acute respiratory distress syndrome: The Berlin definition. JAMA, 2012, 307: 2526-33.
10. Rao MH, A. Muralidhar, A. Krishna Simha Reddy. Acute respiratory distress syndrome.

11. Matthay M, Zemans R. Acute respiratory distress syndrome: pathogenesis and treatment. Annu Rev Pathol, 2011, 6:147-63.

12. Pierrakos C, Karanikolas M, Scolletta S, Karamouzos V, Velissaris D. Acute respiratory distress syndrome: pathophysiology and theraupetic option. J Clin Med Res, 2011, 4(1): 7-16.

13. Koh Y. Update in acute respiratory distress syndrome. Journal of Intensive Care, 2014;2:2.

14. Fanelli V, Vlachou A, Simonetti U, Slutsky AS, Zhang H. Acute respiratory distress syndrome: new definition, current and therapeutic options. Journal of Thoracic Disease. 2013, 5(3): 326-34.

15. Huppert LA, Matthay MA, Ware LB. Pathogenesis of acute respiratory distress syndrome. Semin Respir Crit Care Med, 2019, 40:31-9.

16. Han SH, Mallampalli RK. Acute respitarory syndrome. J Immunol, 2015.

17. Matthay MA, Zemans RL, Zimmerman GA, Arabi YM, Beitler JR, et al. Acute respiratory distress syndrome. Nature Reviews / Disease primers, 2019, 5-18.

18. Peerapur SM. Acute respiratory distress syndrome. 2020.

19. Lee W, Slutsky A. Acute hypoxemic respiatory failure and ARDS. In: Broaddus VC, Ernest JD, Jr TEK and Lazarus SC, Eds). Murray and Nadel textbook of Respiratory Medicine. 6th Ed. Philadelphia: Elseviere, 2016, 1740-60.

20. Delnoi TSR, Driessen R, Sharma AS, Bouman EA, Strauch U, et al. 2016: 9367464.

21. Zwischenberger JB, Bartlett RH. Extrscorporeal life support an overview. In ECMO Extracorporeal Cardiopulmonary Support In Critical Care. 3rd ed/Ann Arbor. MI Extracorporeal life support orgsnization; 2005; $1-4$

22. Journal of thoracic disease; vol 6, no 8 (August 2014): Journal of Thoracic disease (Heart lung 
Transplantation).

23. ELSO Adult Respiratory Failure Guidelines Version 1.4 August 2017

24. Murray JF, Matthay MA, Luce JM, Flick MR. An expanded definition of the adult respiratory distress syndrome. Am Rev Respir Dis 1988;138:720-3.

25. Pillai AK, Bhatti Z, Bosserman AJ, Mathew MC, Vaidehi K, Kalva SJ et al. Management of vascular Complications of Extracorporeal membrane oxygenation. Cardiovasc Diagn ther 2018;8(3):372-377

26. Sidebothan D, FANZCA. Extracorporeal membrane oxygenation. JECT. 2011;43:P23P26.

27. Brogan et al. ELSO Red Book. 5th edition

28. Murphy DA, Hockings LE, Andrews RK, Aubron C, Gardiner EE, Pellegrino VA et al. Extracorporeal membrane oxygenation hemostatic complications. Transfusion Medicine Review. December 2014.

29. Pneumatikos I and Papaioannou V. The New Berlin Definition: What Is, Finally, the ARDS? Pneumon: Quarterly Medical Journal. 2012; 25: 365-8.

30. De Freitas Chaves RC, Robello Filho R, Tavares Timenevsky K, Tanzillo Moreira F, Da Siva Vilanova LC, De Arudda Bravim B, et al. Extracorporeal membrane Oxygenation: a literature review. Rev Bras ter Intensiva. 2019;31(3):410-424.

31. Kozinn J, Wrisinger WC. ECMO untuk kegagalan pernafasan berat dewasa. MMed Journal 2019 Jan-Feb; 116 (1): 58-62.

32. De Freitas C, Filhorr, Timenetsky KT, Moreir FT, Vilanora LC, De Amuda Bravim B, et al. Extracorporeal membrane oxygenation: a Literature review. Rev Bras Ter Intensive. 2019; 31(3): $410-424$.

33. Guo Z, Sun L, Li B, Tian R, Zhang X, Zhang Z. Anticoagulan management in Severe Corona virus Diseae 2019 patients on Extracorporeal membran Oxygenation. Journal of Cardiothoracic and Vascular Anesthesia (2020)
19

34. Romano TG, Mendes PV, park M, Viera Costa EL. Extracorporeal respiratory support in adults patients. J Bras Pneumol. 2017; 43(1): 60-70. 